\title{
Defining Mainstreams Of Innovation: A Literature Review
}

\author{
Edy Suroso $^{1}$, Yudi Azis ${ }^{2}$ \\ ${ }^{1}$ Doctoral program student of Department of Management Padjadjaran University Bandung Indonesia /Department of \\ Management Siliwangi University Tasikmalaya Indonesia \\ ${ }^{2}$ Department of Management Padjadjaran University Bandung Indonesia
}

\begin{abstract}
The importance of innovation in current business justifies the increasing interest that researchers are taking in it. This propose of this article is to identify and organize the overall innovation research current state to investigate and analysis the key findings of these studies.The method used in this article was systematic review of empirical and conceptual article published in scholarly reviews on topic of innovation.The findings shows (1) There are three mainstreams innovation typologies approach dominant: incremental versus radical innovation; technological versus marketing innovation; and product versus process innovation. (2) The literature research in innovation measurement can be divided into two mainstream of innovation measurement; Input and output measurement; Metric and methodologies measurement.
\end{abstract}

Keyword: Innovation, Innovation typologies, Innovation measurement

\section{Introduction}

The expression "innovate or die" has been an accepted phrase in the popular business environment (Kavadas and Chao, 2007). Innovation is one of most important sources of competitive advantage (Hansen, 2014; Damanpour et al, 2009; Gunday et al, 2011; Lin et al, 2007; Abidin et al, 2013).The study of innovation hardly needs justification as scholars, practitioners and policy makers maintain that innovation is a primary source of competitive advantage, industrial change and economic growth (Boyne et al, 2006).

The undeniable importance of innovation in current business justifies the increasing interest that researchers are taking in it. However, if the number of papers on the topic has evolved exponentially, there is still no precise prescription for successful innovation (Becheikh et al, 2005; Rosenbusch et al, 2010). Several researchers have tested the effect of a large number of innovation-related variables. However, even thought they tested similar variables, they discovereddiffering degrees of association with the rate of innovation (Carayannis and Provance, 2008; Kostopoulos et al, 2010; Projogo and Sohal, 2006; Auken et al, 2008). The innovation process still poorly understood and the current state of the literature contributes little to improving our understanding of phenomenon.

The contribution of this articleis threefold. First, we identify and organize relevant work into innovation domains by following literature review designed to understand innovations context. Second, we assess the overall innovation research current state to investigate and analysis the key findings of these studies in order to identify where the conclusions converge and diverge. This will help to advance our knowledge of innovative performance in companies. Third, we identify limitation of these studies for future research direction.

The structure of the article is as follows. First, we describe the literature on innovation. Next, we will describe the method used to locate and select the relevant literature, and present some general reviewed studies.We will then present and discuss the result of our review, and finish with the main conclusions, implications and recommendations.

\section{Literature Review}

Innovation is widely acknowledged as key to economic development, since it potentially leads to productivity and competitive gains (Abrunhosa\&ESa, 2008).There are several definitions of innovation. According to Schumpeter (1983) "innovation is the commercial or industrial application of something new-a new product, process or method of production; a new market or sources of supply; a new form of commercial business or financial organization.

The European Commission defines innovation as the renewal and enlargement of the range of products and services and the associated markets; the establishment of new methods of production, supply and distribution; the introduction of changes in management, work organization, and the working conditions and skills of the work force (CEC, 1995).

In the simple terms, innovation involves the exploitation of new ideas. Innovation is term that may refer to process, an attribute, or an end result. There is a difference between innovation and invention. Innovationshould not be equated to invention; an invention may not necessarily lead on to innovation. This distinction is made clear by Freeman (1982) when he note that: "an invention is a idea, a sketch or model for a new or improved device, product, process or system" whereas "an innovation in the economic sense is accomplished only with the first commercial transaction involving the new product, process, system or device.."

Different definitions of innovation included in the literature. "Innovation has been consistently defined as the adoption of idea or behavior that is new to the organization (Bon \& Mustafa, 2013). Thus, innovation does not exclusively result from $\mathrm{R} \& \mathrm{D}$; it is a multidimensional process, with multiple sources, most of the time coming from complex interactions among individuals, organization and the institutional setting. 
The method of innovation is to develop ideas, refine them into a useful form, and bring them to fruition in the market where they will achieve increased efficiencies (Morris, 2008). Innovation definitely creates business value. The value manifest itself in different form, e.g., there could be value from radical innovation leading to entirely new products as well as from incremental innovation leading to improvement in existing products.

Innovation is important because in this knowledge era, many companies see it as a strong contributor and means for generating business and profitable growth that will improve an organization's performance and competitiveness (Potters, 2009). Sustainable and profitable growth in a company requires sustainable innovation activities (Gupta, 2007)

From a micro point of view, innovation is management discipline: it focus on he organization's mission, searches for unique opportunities, determines whether they fit the organization's strategic direction, defines the measures for success, and continually reassesses opportunities (Gaynor, 2002 in Lin and Chen 2007).

In general, innovation research can be approached from the perspectives of an individual, an organization, and a nation, focusing on personal traits, innovation management, and nation's source of competitiveness, respectively. Scholars from various disciplines have explored innovation from different perspectives. They have enriched this area of study and enable other researchers to gain a better understanding of the nature of innovation (Lin and Chen, 2007).

\section{Methodology}

The review method used in this article was systematic review of empirical and conceptual article published in referred scholarly reviews on topic of innovation. Before specifying the methodological details of the study, it is worthwhile answering first the question: why to do a systematic review? In the management field, the traditional narrative literature review have been widely criticized for the lack of relevance due to the use of personal, and usually subjective and biased methodology by authors (fink, 1998; Hart, 1998). To mitigate this gap, Transfield et al (2003) propose to apply the specific principles of the systematic review methodology usually use in medical science. The main difference between a systematic review and a traditional narrative review is that, contrary to the later, the former uses a rigorour, replicable, scientific and transparent process (Cook et al., 1997).

A systematic review is, however different from a meta-analysis in the sense that is does not use statistical and econometric procedures for synthesizing findings and analyzing data (Transfieldet. Al., 2003).The main purpose of a systematic review is to identify key findings and contributions to a field or question and its results are often descriptively presented and discussed. Applying the principles of the systematic review will then help to limit bias (systematic errors), reduce chance effects, enhance the legimitacy and authority of the ensuing evidence and provide more reliable results upon which to draw conclusions and make decisions. Two steps are particularly important when doing a systematic review: (1) the setting of inclusion criteria and (2) the strategy of locating and selecting the potential studies (Alderson et al, 2004).

\section{Findings and Discussion Innovation Typologies}

Table1. The Mainstreams of Innovation Typologies

\begin{tabular}{|c|c|c|}
\hline $\begin{array}{l}\text { Mainstreams of } \\
\text { Innovation } \\
\text { Typology }\end{array}$ & Key Characteristics & Prominent Authors \\
\hline $\begin{array}{l}\text { Radical versus } \\
\text { Incremental } \\
\text { Innovation }\end{array}$ & $\begin{array}{l}\text { - Radical innovation are the ones that are new to the world } \\
\text { and are exceptionally different from existing products and } \\
\text { services } \\
\text { - Incremental Innovation involves revisions or alterations to } \\
\text { existing products or service }\end{array}$ & $\begin{array}{l}\text { Abrunhosa and E Sa } \\
\text { (2008), Lin andChen } \\
(2007) \text {, Prajogo and } \\
\text { Sohal (2003), } \\
\text { Forsman and Temel } \\
(2011)\end{array}$ \\
\hline $\begin{array}{l}\text { Technological } \\
\text { versus Marketing } \\
\text { innovation }\end{array}$ & $\begin{array}{l}\text { - Technological innovation is the adoption of new } \\
\text { technologies that are incorporated into processes or product } \\
\text { - Marketing innovation is associated with internal processes } \\
\text { supporting the delivery of a service or product }\end{array}$ & $\begin{array}{l}\text { Rosenbusch (2011), } \\
\text { Damanpour et al } \\
(2009), \text { Auken et al } \\
(2008), \text { Bon and } \\
\text { Mustafa (2013) }\end{array}$ \\
\hline $\begin{array}{l}\text { Product versus } \\
\text { process innovation }\end{array}$ & $\begin{array}{l}\text { - Product innovation are creating a new or improved good or } \\
\text { service } \\
\text { - Process Innovation are focuses on improving the } \\
\text { effectiveness and efficiency of production }\end{array}$ & $\begin{array}{l}\text { Gunday et al (2011), } \\
\text { Sigh and Smith } \\
(2004) \text {, Prajogo and } \\
\text { Sohal (2006) }\end{array}$ \\
\hline
\end{tabular}




\section{Radical versus Incremental Innovation}

One commonly studied typology draws the distinction between radical and incremental innovations (Abrunhosa and $\mathrm{E}$ Sa, 2008; Lin and Chen, 2007; Prajogo and Sohal, 2003, Forsman and Temel, 2011). Radical innovation represent entirely new and different offering through which enterprises aim to get create new markets (Garcia and Calantone, 2002). Radical innovation have been considered as risky actions since they need the time financial resources and expensive knowledge (Cainelli et al., 2006 in Forsman and Temel, 2011).

Looking at the big picture, it is usual to classify innovations as radical or incremental, although, what we have in fact is much more a continuum. at one extreme, we can find those innovations that are so great that they result in a fundamental change in the very nature of a business. Whereas, at the other extreme, there are some innovations that are so minor they are barely perceived as change (Gilbert, 1994 in Abrunhosa and E sa, 2008). If the first perspective is adopted, radical innovation represents the creation $f$ a novelty with commercial-value to the world. In line with this, incremental innovations come in the form of improvements and adaptations that occur as radical innovations are diffused in economic system.

Radical innovations are new and diverse from previous innovations while incremental innovations alter existing products. Radical innovations to be radical it has to be sole and novel and from present innovations or it has influence on the future innovations or both. The most radical innovations are the ones that are new to be the world and are exceptionally different from existing products and services. Whereare incremental innovations involves revisions or alternations to existing products or service. Incremental innovation includes addition of elements of the service, product, or process. This additions improve the way that achieving and increasing customer satisfaction.Incremental innovations represent minor improvement to the existing products, services and processes trough which enterprises often pursue to enhance processes, make operations more effective, improve the quality and decrease costs (Sewar and Dutton, 1986 in Forsman and Temel, 2011).

\section{Technological versus Marketing Innovation}

Technological innovation relating to new products, processes or services, while marketing innovation involves change to social structure of the organization (Rosenbusch, 2011; Damanpour et al, 2009; Auken et al, 2008; Bon and Mustafa, 2013). Technological innovation is the adaption of new technologies that incorporated into processes or products (Damanpour et al, 2009), Technological innovation provides long-term success in market through high competitive advantage (Grover et al, 2007 in Bon and Mustafa, 2013). While marketing innovation refers to implementation of new ideas improve organizational processes, routines, structures, or systems (Elenkov et al, 2005 in Bon and Mustafa, 2013) marketing innovation is associated with internal processes supporting the delivery of a service or product.

Technological innovation refer to any type of innovation structure from a technical viewpoint and which lies at the heart of operations; such innovations influence the flow of product or process operation (Damanpour, 2009). Technological innovation often associated with opportunities available to the organization as a result of advance in technology. Marketing innovation bring change to structure of the organization. Marketing innovation as pertaining to change in the organizational structure and the people who populate the organization. These innovations are assumed to originate in the more peripheral, marketing core of organization.

Marketing innovation is the implementation of a new marketing method involving significant changes in product design or packaging, product placement, product promotion or pricing. Marketing innovations target a addressing customer need better, opening up new markets, or newly positioning a firm's product on the market with the innovation increase firm's sales. Marketing innovations are strongly related to pricing strategies, product package design properties, product placement and promotion activities along the lines of four P's marketing.

\section{Product versus Process Innovation}

Another common typology used in most innovation studies is the distinction between product and process innovations. Product and process innovations are closely related to the concept of technological developments. Product innovation reflect change in end product or services, and process innovation represent change in the way an enterprise produces products and services (Dibrell et al, 2008 in Forsman and Temel, 2011). A product innovation is the introduction of a good or service that is new or significantly improved regarding its characteristics or intended uses. Product innovations can utilize new knowledge or technologies, or can be based on new uses or combinations of existing knowledge or technologies. A process innovation is the implementation of new or significantly improved production or delivery method. Process innovations can be intended to decrease unit costs of production or delivery, to increase quality, or to produce or deliver new or significantly improved product (Gunday et al, 2011).Both of product innovation and process innovation are under technological innovation type. product innovation is creating a new good or service or improved on existing gods or services. Process innovations, on the other hand, are focuses on improving the effectiveness and efficiencies of production.

Product innovation concerned with the development new product and services for the market while process innovation relates to ways of undertaking production or services operations. Product innovation aim to present a new or improved product or service for the customers and customers see the impact of such innovation in the products or services they receive, while process innovations change or improve the way organizations perform.

Product innovations can utilize new knowledge or technologies, or combinations of existing knowledge or technologies. The term product covers both goods and services. Product innovation is a difficult process driven by advancing technologies, changing customer needs, shortening product life cycles, and increasing global competition. Process innovation is a new or significantly improved production or delivery method. 
This includes significant change in techniques, equipment and/or software. Process innovations can be intended to decrease unit costs of production or delivery, to increase quality, or to produce or deliver new or significantly improved products.
Product innovation can be used to strategically differentiate an organization's product offerings in the marketplace, thereby satisfying market demands, building customer loyalty, and improving firm performance. Process innovation denotes a process of renewal within organizations (Huang and Rice, 2012).

Innovation Measurements

Table 2. The Mainstreams of Innovation Measurements

\begin{tabular}{|c|c|c|}
\hline $\begin{array}{l}\text { Mainstreams of } \\
\text { Innovation } \\
\text { Measurements }\end{array}$ & Key Characteristics & Prominent Authors \\
\hline $\begin{array}{l}\text { Input and output } \\
\text { measurement }\end{array}$ & $\begin{array}{l}\text { Researcher stress the importance of output } \\
\text { indicators in measurement, but most of the } \\
\text { research is still predominantly focused on } \\
\text { input }\end{array}$ & $\begin{array}{l}\text { Azis\&Osada (2009), } \\
\text { Azis\&Osada (2013), Gunday et } \\
\text { al (2011), Auken et al (2008), } \\
\text { Hoang and Igel(2006), Sigh and } \\
\text { Smith (2004), Prajogo and } \\
\text { Sohal (2003), Prajogo and Sohal } \\
(2006) \text { Bon and Mustafa } \\
(2013)\end{array}$ \\
\hline $\begin{array}{l}\text { Metric } \\
\text { methodologies } \\
\text { measurement }\end{array}$ & $\begin{array}{l}\text { Surveys, questionnaires, balance scorecard, } \\
\text { various mathematical model, and other } \\
\text { methods have been developed to measure } \\
\text { innovation. Different standards and } \\
\text { methodologies are being used in different } \\
\text { companies or organization }\end{array}$ & $\begin{array}{l}\text { Abidin et al (2011), Damanpur } \\
\text { (2009), Lin and Chen (2007), } \\
\text { Abrunhosa (2008), Carpinetti et } \\
\text { al (2007), Carayannis and } \\
\text { Provance (2008), Siguaw et al } \\
\text { (2006), Rosenbusch (2011), } \\
\text { Abidin et al (2013), Adams et al } \\
\text { (2006) }\end{array}$ \\
\hline
\end{tabular}

Measuring Innovation has attracted many researcher, who have conducted studies to measure innovation by using different methodologies and indicators. some measure innovation based on single indicator, while others focus on several indicators. The literature research in innovation measurement can be divided into two mainstreams.

\section{Input and output Measurement}

First, Input and output measurement, the literature search shows that many companies measure their innovation by considering a combination of input and output indicators. The focus of the most of the research is on specific area such as high-tech industry, service industry, private and public sectors, knowledge-based firms, forest industry, and pharmaceutical. In the existing literature, it was identified that the measurement has always focus on input indicators, some times combined with output indicators. However, measuring innovation by taking inputs into account bring bias into the results since inputs are controllable. Output demonstrates the results of innovation while input is just an enabler of innovation.
Inputs indicators mainly measure resources that are put into the innovation process. These inputs include intellectual, human and technological capital. Outputs indicators represent the realized, shorter term success of innovative activity. Indicators of this group count patent numbers and rates, patent quotes, number of new product, percentage of sales with innovations and others.

Outputs are uncontrollable and unpredictable while inputs and processes can be managed and controlled by the company. Measuring something that can be controlled and manage from within the firm biased the results. For example, a company can increase their $R \& D$ expenditures as high as it wants; however, that increase does not necessarily assure that the company is highly innovate. Simply having high inputs may or may not produce high outputs.

Many studies use a single input or output indicators to determine the innovative performance of firm. It has been shown, however, that there are measurement problems with innovation, especially with input indicators. Critical issues include: (1) some input measurements that do not capture process efficiency, (2) single measurements that do not reflect 
economic or qualitative value, (3) lack of indication of technological complexity in the inputs.

Output indicators that are based on patents might be problematic because technological level and the economic value of patents are highly heterogeneous, the nature of the patent content varies widely across countries, not all innovations are patented, not all patent become innovations and the propensity to patent varies Great with firm size. Furthermore, output indicators shows limitations due industry level antecedents when multiple industries or firm sizes are compared. Advancing the criticism, we have identified three limitations of the existing literature. The emphasis is primarily put on: (1) the manufacturing sector, (2) product innovations, while ignoring, (3) process variables.

In the existing literature, it was identified that the measurement has always focused on input indicators, sometimes combined with output indicators. However, measuring innovation by taking inputs into account bring bias into the results since inputs are controllable. Output demonstrates the results of innovation while input is enabler of innovation.

The literature emphasizes the need for identifying more output indicators and a measurement framework that is based merely on output indicators. Some research by practitioners measures innovativenessby taking several indicators into account. However, the research failed to identify that not all indicators have the same importance for assessing he innovativeness of a company.

\section{Metric and Methodologies Measurement}

The Second mainstream of innovation measurement focuses on metric and the methodologies to measure innovativeness. Numerous studies have been conducted to measure innovation of a firm, each ne using different metricand methodologies.Literature research has also identified numerous methodologies to measure innovativeness. However, it is very difficult for a company to measure and benchmark itself with others if everybody is using different methodologies. The literature has identified the need to have a general conceptual framework to measure innovativeness.

Lin and Chen (2007), Abrunhosa (2008), Carpinetti et al (2007), Carayannis and Provance (2008) identifies metric for measurement and categories them into corporate metrics and business metric in their report, They also stresses that different sectors might have different measurement mechanisms and highlights the importance of attaching the input indicators to the output indicators. The methodologies being used to measure innovativeness by scholars and practitioner are literature review, interviews, factor analysis, cluster analysis, Survey, case study, and Delphi method.

Some research by practitioner measure innovativeness by taking several indicators into account. However, the research failed to identify that not all indicators have the same importance for assessing the innovativeness of a company. The relative importance of the indicators was assessed by comparing two indicators at the same time. The pairwise comparison method was utilized to determine the relative importance of each indicator to the innovativeness of a company.

\section{Conclusion}

Understanding and knowing innovation typologies are essential for organizations and researcherasserted that typology of innovation many and varies between studies. The concept of type of innovation is central to innovations research and practice, and therefore received considerable attention from many authors. This paper has undertaken a through literature review to surface key characteristics, typologies and definitions of the various types of innovation. There are three mainstreams innovation typologies approach dominant: incremental versus radical innovation; technological versus marketing innovation; and product versus process innovation.

Radical innovation are the ones that are new to the world and are exceptionally different from existing products and services, while incremental Innovation involves revisions or alterations to existing products or services. Technological innovation is the adoption of new technologies that are incorporated into processes or products, while marketing innovation is associated with internal processes supporting the delivery of a service or product. Product innovation are creating a new or improved good or service, while process Innovation are focuses on improving the effectiveness and efficiency of production.

This paper makes a contribution to understanding of innovation typologies by offering some insights into term and terminology associated with types of innovation. These innovation typologies can be used by both academics and practitioners as a guide and repository of innovation typologies. This paper highlights the lack of research under the notions of position and specifically paradigm innovation this pose a challenge/opportunity for scholars to further study and explore these innovation typologies.

Measuring Innovation has attracted many researchers, who have conducted studies to measure innovation by using different methodologies and indicators. The literature research in innovation measurement can be divided into two mainstream of innovation measurement; Input and output measurement; Metric and methodologies measurement.This fact, coupled with the diversity of the measurements used by researchers, make analyzing and understanding this phenomenon challenging and ay attempt to compare and generalize the result difficult.

\section{References}

Abidin, S.Z., Mokhtar, S.S., Yusoff, R. Z., (2011), Systematic Analysis of Innovation Studies: A Proposed Framework on Relationship Between Innovation Process and Firm's Performance, The Asian Journal of Technology Management, Vol. 4 No. 2 pp. 6583.

Abidin, S.Z., Mohtar, S.S., Yusoff, R.Z., (2013) Innovation process from the perspective of measurement, International journal of innovation and applied Studies, Vol. 3 No. 1 pp. 255-261. 
Abrunhosa, A., E Sa', P.M, (2008), Are TQM principles supporting innovation in Portuguese footwear industry, Journal of technovation, Vol. 28 pp. 208 221.

Adams, R., Bessant J., Phelps, R., (2006), Innovation management measurement: A review, International Journal of Management Reviews, Vol. 8 Issue 1 pp. 21-47

Alderson, P., Green, S., Higgins, J.P.T., (Eds), 2004, Cochrane Reviews' Handbook 4.2.2. Cochrane Library, IssueI. Wiley, Chichester, UK.

Anton MulyonoAzis, YudiAzis (2013), Foundation and Basic Information in Designing Performance Management System, International Journal of Innovations in Business, vol 2, no 4, pp 327-349

Aoun, M., Hasnan, N. (2013), Lean Production and TQM: Complementary or Contradictory Driving Forces of Innovation Performance?, International Journal of Innovation Science Vol. 5 No.4 pp. 237 - 252.

Auken, H., Guijarro, A.M., Lema, D.G., (2008), Innovation and performance in Spanish manufacturing SMEs, International Journal of Entrepreneurship and Innovation Management, Vol. 8 No. 1 pp. 36-56

Azis, Y., \&Osada, H. (2010). Innovation in management system by Six Sigma: an empirical study of world-class companies. International Journal of Lean Six Sigma, 1(3), 172-190.

Azis, Y and Osada, H (2013), Managing Innovation Using Design For Six Sigma (Dfss) Approach In Healthcare Service Organizations,International Journal of Innovation and Technology Management, vol 10 , no 3

Azis, Y and Hiroshi Osada (2009), Six Sigma impact on innovation of management system and its comparison with TQM, Proceedings of the 7th ANQ congress Tokyo

Becheikh, N., Landry, R., Amara, N. (2006), Lessons from innovation empirical studies in he manufacturing sector: A systematic review of literature from 1993 - 2003, Technovation Vol. 26 pp. 644-664Gamarra, J.T., Zawislak P.A. (2013) Transactional Capability: Innovation's missing link, Journal of Economics, Finance and Administrative Science, Vo. 18 No. 34 pp 2-8.

Bon, A.T., Mustafa, E.M.A., (2013), Impact of Total Quality Management on Innovation in Service Organizations: Literature review and New Conceptual Framework, Procedia Engineering, Vol. 53 pp. 516-529.

Boyne, G. A., Meier, K. J., O’Tole, L. J. Jr. and Walker, R. M. (2006), Public Service Performance, Perspectives on Measurement and Management. Cambridge: Cambridge University Press

Carpinetti, L. C. R., Gerolamo, M. C. G., Galda'mez, E. V. C., (2007), Continuous Innovation and Performance Management of SME Clusters, Creativity and Innovation Management, Vol. 16 No. 4 pp. 376-385.
Carayannis, E.G., Provance, M., (2008), Measuring firm innovativeness: towards a composite innovation index built on firm innovative posture, propensity and performance attributes, International Journal of Innovation and Regional Development, Vol. 1 No. 1 pp. 90-107.

CEC, (1995), Green Paper on Innovation, COM (95) 688

Cook, D.J., Mulrow, C.D., Haynes, R.B., 1997, Systematic reviews: synthesis of best evidence for clinical decisions. Annals of internal Medecine 126 (5) 379380.

Damanpour, F., Walker, R.M., Avellaneda, C.N., (2009), Combinative effects of Innovation Types and Organizational Performance: A Longitudinal Study of Service Organizations, Journal of Management Studies, Vol. 46 No. 4 pp. 650-675.

Ehigie, B. O., McAndrew, E. B., (2005), Innovation, diffusion and adoption of total quality management (TQM), Management Decision, Vol. 43 No. 6 pp. 925-940.

Fink, A, 1998, Conducting Research Literature Reviews: from paper to the internet. Sage Publication, London

Freeman, C., (1982), The economics of industrial innovation, London: Frances Pinter

Forsman, H. and Temel, S., 2011. Innovation and Business Performance in Small Enterprises. An EnterprisesLevel Analysis, International Journal of Innovation Management, Vol. 15 No. 3 pp. 641-665

Gamarra, J.T. \&Zawislak P.A. (2013) Transactional Capability: Innovation's missing link, Journal of Economics, Finance and Administrative Science, Vol. 18 No. 34 pp. 2-8

Garcia, R. and Calantone, R., 2002, A Critical look at technological innovation typology and innovativeness terminology; A literature review. Journal of Product Innovation Mnagement, 19 (2) pp. $110-132$

Gufta, P., (2007), Firm Specific Measure of Innovation, Chicago

Gunday, G., Ulusoy, G., Kilic, K., Alpkan, L., (2011), Effects of Innovation Types on Firm Performance, International Journal of Production Economic, Vol. 133 pp. 662-676.

Hansen, E., 2014, Innovativeness in the face of decline performance implication, International Journal of Innovation Management, Vol 18. N0. 5 pp. 1450039-1 - 20

Hart, C., 1998, Doing a Literature Review: Releasing the Social Science Research Imagination. Sage Publications, London.

Hoang, T.D., Igel, B., (2005), The Impact of total quality management on innovation Findings from a developing country, International Journal of Quality \& Reliability Management, Vol. 23 No. 9 pp. 10921117.

Huang, F., Rice, J., 2012, Openness in product and process innovation, International Journal of innovation Management, Vol. 16 No. 4 pp. 1250020 -1 -24. 
Kari, H., Tapani, T., (2014), The Innovation Funnel Fallacy, International Journal of Innovation Science, Vol. 6 No. 2 pp. 63-71.

Kim, S.K., (2014), Explicit Design of Innovation Performance Metrics by Using Analytic Hierarchy Process Expansion, International Journal of Mathematics and Mathematical Sciences, Vol. 2014 pp. 1-7.

Kavadas, S., Chao, R.O., (2007), Resources Allocation and New Product Development Portfolio Management, in Handbook of New Product Development Research, Oxport:Elsevier/Butterworth

Kostopoulus, K., Papalexandris, A., Papachroni, M., Loannou, G., (2010), Absorptive capacity, innovation, and financial performance, Journal of Business Research JBR-07093; No of Pages 9.

Lin C.Y, Chen Y.C., (2007), Does innovation lead to performance? An empirical study of SME's in Taiwan, Management research news, Vol. 30 No. 2 pp. $115-132$.

Lawson, B., Samson, D., (2001), Developing Innovation Capability in organization: A dynamic capability approach, International Journal of Innovation Management, Vol. 5 No. 3 pp. 377-400

Maleyeff, J., (2011), Factors Impacting Innovation in New Service Offerings, Journal of Service Science and Management, Vol. 4 pp. 111-117.

Musthaq, N., Peng W. W., Lin, S. ., (2011), Exploring the Lost Link Between TQM, Innovation and Organization Financial Performance through Non Financial Measure, IPEDR Vol. 14 pp. 27-33.

Parast, M.M., (2011), The Effects of Six Sigma projects on innovation and firm performance, International Journal of Project Management, Vol. 29 pp. 45-55.

Potters, L., (2009), Innovation Input and Output: Differences among sector, Communities No. 10 pp. 38

Philips. J. (2010), Open Innovation Typology, International Journal of Innovation Science, Vol. 2 No. 4 pp. 175183
Prajogo, D.I., Sohal, A.S., (2006), The integration of TQM and technology/R\&D management in determining quality and innovation performance, The International Journal of Management Science, Vol. 34 pp. 296-312

Prajogo, D.I., Sohal, A.S., (2003), The relationship between TQM practices, quality performance, and innovation performance, International Journal of Quality \& Reliability Management, Vol. 20 No.8 pp. 901-918.

Rosenbusch, N., Brinckmann, J., Bausch, A., (2009), Is innovation always beneficial? A meta-analysis of the relationship between innovation and performance in SMEs, Journal of Business Venturing, Vol. 26 pp. 441-457.

Rowley, J., Baregheh, A., Smbrook, S., 2011, Towards an innovation-type mapping tool, Management Decision, Vol. 49 No. 1 pp. 73-86.

Schumpeter, J. A., and Opie, R., (1983), The theory of economic development: An inquiry into profits, capital, credit, interest, and the business cycle. New Brunswick, N.J. Transaction Book.

Siguaw, J.A. (2006), Conceptualizing Innovation orientation: A framework for study and integration on Innovation research, The Journal of Product Innovation Management, Vo. 23 pp. 556 - 57.

Singh, P.J., Smith, A.J.R., (2004), Relationship between TQM and Innovation: an empirical study, Journal of Manufacturing Technology Management, Vol. 15 No. 5 pp. 394-401.

Trasfield, D.,Denyer, D., Palminder, S., 2003, Towards a methodology for developing evidence-informed management knowledge by means of systematic review. British Journal of Management 14, 9961004

Zehir, C., Ertosun, O.G., Zehir. S., Muceldili, B., (2012), Total Quality Management Practices' effects on Quality Performance and Innovation Performance, Procedia Social and Behavioral Sciences, Vol. 41 pp. 273280. 
Appendix. The Raw material of literature review

\begin{tabular}{|c|c|c|c|c|}
\hline Authors (Year) & Method & Key Finding & Limitation & $\begin{array}{c}\text { Future Research } \\
\text { Direction }\end{array}$ \\
\hline Aoun\&Hasan (2013) & $\begin{array}{l}\text { Literature } \\
\text { Review from } \\
\text { recent studies }\end{array}$ & $\begin{array}{l}\text { The authors shows that there } \\
\text { is a Complementary } \\
\text { relationship between lean } \\
\text { production and TQM as } \\
\text { driving forces of innovation } \\
\text { performance }\end{array}$ & $\begin{array}{l}\text { - Method of } \\
\text { literature } \\
\text { aren't } \\
\text { explained } \\
\\
\text { - Sources of } \\
\text { literature } \\
\text { mostly from } \\
\text { proceeding } \\
\text { and blog } \\
\text { - no specific } \\
\text { application } \\
\text { has been } \\
\text { discussed }\end{array}$ & $\begin{array}{l}\text { - Using a systematic } \\
\text { review method in } \\
\text { literature study; } \\
\text { Confirmatory } \\
\text { testing using } \\
\text { statistical method } \\
\text { - using more reliable } \\
\text { sources of } \\
\text { literature i.e. } \\
\text { referred journal } \\
\text { - potential } \\
\text { application in } \\
\text { SME's }\end{array}$ \\
\hline $\begin{array}{l}\text { Gamarra\&Zawislak } \\
\text { (2013) }\end{array}$ & $\begin{array}{l}\text { Literature } \\
\text { Review }\end{array}$ & $\begin{array}{l}\text { The identification of } \\
\text { transactional capability as } \\
\text { the missing in innovation }\end{array}$ & $\begin{array}{l}\text { limited as } \\
\text { theoretical } \\
\text { paper in which } \\
\text { no empirical } \\
\text { evidence }\end{array}$ & $\begin{array}{l}\text { Investigate } \\
\text { operasionalization of } \\
\text { framework using } \\
\text { survey study }\end{array}$ \\
\hline Siguaw et al (2006) & $\begin{array}{l}\text { Literature } \\
\text { Review past } 35 \\
\text { years }\end{array}$ & $\begin{array}{l}\text { - examines the vast } \\
\text { innovation literature to } \\
\text { arrive at a clear definition } \\
\text { of innovation orientation } \\
\text { construct to provide a } \\
\text { consistent } \\
\text { conceptualization for } \\
\text { future research } \\
\text { - develops a comprehensive, } \\
\text { organized framework for } \\
\text { understanding innovation } \\
\text { orientation and its effects }\end{array}$ & $\begin{array}{l}\text { - } \begin{array}{l}\text { no standard } \\
\text { measurement } \\
\text { of innovation } \\
\text { orientation }\end{array} \\
\\
\text { - limited as } \\
\text { theoretical } \\
\text { paper in } \\
\text { which no } \\
\text { empirical } \\
\text { evidence }\end{array}$ & $\begin{array}{l}\text { - Development of a } \\
\text { standard measure of } \\
\text { innovation } \\
\text { orientation based on } \\
\text { the elements } \\
\text { defined in this study } \\
\text { - Examine } \\
\text { empirically the } \\
\text { effects of } \\
\text { innovation } \\
\text { orientation on } \\
\text { innovation }\end{array}$ \\
\hline Becheikh et al (2006) & $\begin{array}{l}\text { Systematic } \\
\text { review of } \\
\text { empirical } \\
\text { studies } \\
\text { published } \\
\text { between } 1993 \\
\text { and } 2003 \\
\end{array}$ & $\begin{array}{l}\text { Confirmedthe complexity of } \\
\text { innovation process by } \\
\text { assessing he main internal } \\
\text { and contextual variables } \\
\text { which influence he } \\
\text { innovative capacity of } \\
\text { manufacturing firm }\end{array}$ & $\begin{array}{l}\text { process } \\
\text { innovations are } \\
\text { largely } \\
\text { understudied }\end{array}$ & $\begin{array}{l}\text { investigate this } \\
\text { particular type of } \\
\text { innovation }\end{array}$ \\
\hline Lin et al (2007) & $\begin{array}{l}\text { Telephone } \\
\text { Survey from } \\
877 \text { SMEs in } \\
\text { Taiwan }\end{array}$ & $\begin{array}{l}\text { - About } 80 \% \text { of he } \\
\text { surveyed companies } \\
\text { implemented some sort of } \\
\text { innovation } \\
\text { - } \text { The role administrative } \\
\text { innovation plays in } \\
\text { relation to company sales } \\
\text { - Firm size appear to } \\
\text { explain a major portion } \\
\text { of company sales }\end{array}$ & $\begin{array}{l}\text { with telephone } \\
\text { survey,valuable } \\
\text { information } \\
\text { may have been } \\
\text { lost with such } \\
\text { simple answer }\end{array}$ & Large-scale survey \\
\hline Authors (Year) & Method & Key Finding & Limitation & $\begin{array}{c}\text { Future Research } \\
\text { Direction }\end{array}$ \\
\hline Abidin et al (2013) & $\begin{array}{l}\text { Literature } \\
\text { review from } \\
\text { previous studies }\end{array}$ & $\begin{array}{l}\text { Propose two kinds of } \\
\text { measurements: objective and } \\
\text { subjective innovation }\end{array}$ & $\begin{array}{l}\text { Limited } \\
\text { sources of } \\
\text { literaure }\end{array}$ & $\begin{array}{l}\text { Adding sources of } \\
\text { lierature }\end{array}$ \\
\hline
\end{tabular}




\begin{tabular}{|c|c|c|c|c|}
\hline & & process measure & & \\
\hline $\begin{array}{l}\text { Abrunhosa\& E Sa } \\
\text { (2008) }\end{array}$ & Regression & $\begin{array}{l}\text { Give support to the view in } \\
\text { fact TQM principles have a } \\
\text { positive association with the } \\
\text { adoption of technological } \\
\text { innvation }\end{array}$ & $\begin{array}{l}\text { - Being } \\
\text { concentrated } \\
\text { in a particular } \\
\text { industry } \\
\text { - Relies on } \\
\text { perceptual } \\
\text { from top } \\
\text { managers } \\
\text { only }\end{array}$ & $\begin{array}{l}\text { - } \begin{array}{l}\text { conducted in other } \\
\text { industries }\end{array} \\
\text { - Based on multiple } \\
\text { respondent }\end{array}$ \\
\hline $\begin{array}{l}\text { Prajogo\&Sohal } \\
\text { (2003) }\end{array}$ & $\begin{array}{l}\text { Survey of } 194 \\
\text { managers in } \\
\text { Australian } \\
\text { industry } \\
\text { encompassing } \\
\text { both } \\
\text { manufacturing } \\
\text { and non- } \\
\text { manufacuring } \\
\text { sectors, SEM }\end{array}$ & $\begin{array}{l}\text { - TQM significantly and } \\
\text { positively contributes to } \\
\text { contributes t innovation } \\
\text { performance } \\
\text { - Positive and significant } \\
\text { relationship between } \\
\text { quality performance and } \\
\text { innovation performance }\end{array}$ & $\begin{array}{l}\text { examination in } \\
\text { develop } \\
\text { country }\end{array}$ & $\begin{array}{l}\text { Conducted in } \\
\text { developing country }\end{array}$ \\
\hline Adams et al (2006) & $\begin{array}{l}\text { Literature } \\
\text { review }\end{array}$ & $\begin{array}{l}\text { - Develop a framework of } \\
\text { he innovation process } \\
\text { consisting of seven } \\
\text { categories }\end{array}$ & $\begin{array}{l}\text { No reliability } \\
\text { and validity } \\
\text { asessment }\end{array}$ & $\begin{array}{l}\text { Examine reliability } \\
\text { and validity asessment }\end{array}$ \\
\hline $\begin{array}{l}\text { Lawson \& Samson } \\
\text { (2001) }\end{array}$ & $\begin{array}{l}\text { Literature } \\
\text { review \& case } \\
\text { study on Cisco }\end{array}$ & $\begin{array}{l}\text { Proposed innovation } \\
\text { capability's construct with } \\
\text { seven element }\end{array}$ & $\begin{array}{l}\text { No validity \& } \\
\text { empirical } \\
\text { testing }\end{array}$ & $\begin{array}{l}\text { Refine validated and } \\
\text { tested using surveys }\end{array}$ \\
\hline Bn\& Mustafa (2013) & $\begin{array}{l}\text { Literature } \\
\text { review }\end{array}$ & $\begin{array}{l}\text { Studies on TQM and } \\
\text { Innovation relationship are } \\
\text { still scarce in literature }\end{array}$ & $\begin{array}{l}\text { Limited as } \\
\text { propose } \\
\text { conceptual } \\
\text { framework and } \\
\text { model } \\
\end{array}$ & $\begin{array}{l}\text { Examine empirically } \\
\text { of TQM and } \\
\text { Innovation } \\
\text { relationship }\end{array}$ \\
\hline Mushtaq et al (2011) & $\begin{array}{l}\text { Literature } \\
\text { review }\end{array}$ & $\begin{array}{l}\text { There exist a link between } \\
\text { TQM, innovation and firm's } \\
\text { non financial and financial } \\
\text { performance }\end{array}$ & $\begin{array}{l}\text { Has no been } \\
\text { studied } \\
\text { explicitly in } \\
\text { literature and } \\
\text { therefore } \\
\text { requires more } \\
\text { investigation }\end{array}$ & $\begin{array}{l}\text { A SEM modeling } \\
\text { approach would be the } \\
\text { most appropriate } \\
\text { method to investigate } \\
\text { this relationship }\end{array}$ \\
\hline Abidin et al (2011) & $\begin{array}{l}\text { Literature } \\
\text { review }\end{array}$ & $\begin{array}{l}\text { Proposes six constructs } \\
\text { which can be used to } \\
\text { examine the innovation } \\
\text { implementation at firm level } \\
\text { Reference model to research } \\
\text { the relationship between } \\
\text { innovation process, } \\
\text { innovation outcome and } \\
\text { firm's performance }\end{array}$ & $\begin{array}{l}\text { Limited as } \\
\text { propose model } \\
\text { to research }\end{array}$ & $\begin{array}{l}\text { Examine empirically } \\
\text { the effects of the } \\
\text { relationship between } \\
\text { innovation process, } \\
\text { innovation outcome } \\
\text { and firm's } \\
\text { performance }\end{array}$ \\
\hline Authors (Year) & Method & Key Finding & Limitation & $\begin{array}{c}\text { Future Research } \\
\text { Direction }\end{array}$ \\
\hline Projogi\&Sohal (2006) & $\begin{array}{l}\text { Structural } \\
\text { Equation } \\
\text { Modeling } \\
\text { (SEM) } \\
\text { technique }\end{array}$ & $\begin{array}{l}\text { TQM shows a strong } \\
\text { predictive power against } \\
\text { quality performance but no } \\
\text { significant relationship } \\
\text { against innovation } \\
\text { performance on the other } \\
\text { hand technology and R\&D } \\
\text { management shows a }\end{array}$ & $\begin{array}{l}\text { Limited as a } \\
\text { period time }\end{array}$ & $\begin{array}{l}\text { Requires longitudinal } \\
\text { data }\end{array}$ \\
\hline
\end{tabular}




\begin{tabular}{|c|c|c|c|c|}
\hline & & $\begin{array}{l}\text { significant relationship with } \\
\text { quality performance but at a } \\
\text { lower level than that of } \\
\text { TQM, and shows much } \\
\text { stronger relationship with } \\
\text { innovation performance }\end{array}$ & & \\
\hline Singh \& Smith (2004) & $\begin{array}{l}\text { Survey of } 418 \\
\text { Australian } \\
\text { manufacturing } \\
\text { organizations, } \\
\text { SEM }\end{array}$ & $\begin{array}{l}\text { There is insufficient } \\
\text { statistical evidence to } \\
\text { suggest that TQM is related } \\
\text { to innovation }\end{array}$ & $\begin{array}{l}\text { simple linear } \\
\text { relationship } \\
\text { model }\end{array}$ & $\begin{array}{l}\text { Examine if indeed } \\
\text { there is empirical } \\
\text { support for these more } \\
\text { complex models }\end{array}$ \\
\hline Hoang \&Igel (2005) & $\begin{array}{l}\text { Confirmatory } \\
\text { factor analysis, } \\
\text { empirical } \\
\text { analysis in } \\
\text { Vietnam }\end{array}$ & $\begin{array}{l}\text { - Has a positive impact on } \\
\text { the firm's innovativeness } \\
\text { - Not all TQM practices } \\
\text { enhance firm } \\
\text { innovativeness only } \\
\text { leadership and people } \\
\text { management, process and } \\
\text { strategic management and } \\
\text { open organization showed } \\
\text { a positive impact on the } \\
\text { firm's innovation } \\
\text { performance }\end{array}$ & $\begin{array}{l}\text { - The sample } \\
\text { was not } \\
\text { random } \\
\\
\text { - assessed } \\
\text { concept of } \\
\text { newness with } \\
\text { company } \\
\text { boundaries }\end{array}$ & $\begin{array}{l}\text { select different } \\
\text { random sample to } \\
\text { allow for more } \\
\text { generalization of } \\
\text { the result } \\
\text { - should measure } \\
\text { newness within the } \\
\text { boundaries of the } \\
\text { specific industry }\end{array}$ \\
\hline $\begin{array}{l}\text { Ehigie\&McAndrew } \\
\text { (2005) }\end{array}$ & $\begin{array}{l}\text { The approach } \\
\text { for data } \\
\text { collection is } \\
\text { basically } \\
\text { secondary } \\
\text { sources }\end{array}$ & $\begin{array}{l}\text { - From reviews made it is } \\
\text { argued that, although } \\
\text { TQM looks faddish in } \\
\text { graphical presentation of } \\
\text { articles on TQM, it cannot } \\
\text { be concluded that it is now } \\
\text { a management fad. } \\
\text { - Thought report on TQM } \\
\text { seem to diminish among } \\
\text { popular press but } \\
\text { academic scholars are still } \\
\text { very much angrossed with } \\
\text { empirical studies on TQM. } \\
\text { - This is based on the fact } \\
\text { that many organization } \\
\text { still adopt and implement } \\
\text { TQM and its diffusion is } \\
\text { on the increase globally }\end{array}$ & $\begin{array}{l}\text { The main } \\
\text { source of } \\
\text { literature for } \\
\text { presentation is } \\
\text { the ABI- } \\
\text { INFORM } \\
\text { database }\end{array}$ & $\begin{array}{l}\text { Encouraged for other } \\
\text { sources of literature to } \\
\text { be explored }\end{array}$ \\
\hline Authors (Year) & Method & Key Finding & Limitation & $\begin{array}{c}\text { Future Research } \\
\text { Direction }\end{array}$ \\
\hline $\begin{array}{l}\text { Kostopoulus et al } \\
\text { (2010) }\end{array}$ & $\begin{array}{l}\text { - Survey in a } \\
\text { sample of } \\
461 \text { Greek } \\
\text { enterprises } \\
\text { - Using path } \\
\text { analysis }\end{array}$ & $\begin{array}{l}\text { - Directed related t } \\
\text { absorptive capacity and } \\
\text { indirectly related to } \\
\text { innovation and financial } \\
\text { performance }\end{array}$ & $\begin{array}{l}\begin{array}{l}\text { Some Data } \\
\text { are of self- } \\
\text { report }\end{array} \\
\text { - } \begin{array}{l}\text { Test } \\
\text { concerns of } \\
\text { nationality }\end{array}\end{array}$ & $\begin{array}{l}\text { - Collecting objective } \\
\text { financial } \\
\text { performance data } \\
\text { from a different } \\
\text { surce } \\
\text { - examine other } \\
\text { country }\end{array}$ \\
\hline Carpinetti et al (2007) & $\begin{array}{l}\text { Literature } \\
\text { review }\end{array}$ & $\begin{array}{l}\text { - Despite some difficulties } \\
\text { in developing and using } \\
\text { performance indicator in } \\
\text { SMEs } \\
\text { - Propose model can help to }\end{array}$ & $\begin{array}{l}\text { Limited as } \\
\text { conceptual } \\
\text { model }\end{array}$ & $\begin{array}{l}\text { Examine empirical } \\
\text { studies }\end{array}$ \\
\hline
\end{tabular}




\begin{tabular}{|c|c|c|c|c|}
\hline & & $\begin{array}{l}\text { foster cooperation and } \\
\text { maturity in continuous } \\
\text { innovation in cluster } \mathrm{f} \\
\text { SMEs }\end{array}$ & & \\
\hline $\begin{array}{l}\text { Carayannis\&Provance } \\
(2008)\end{array}$ & $\begin{array}{l}\text { - Composite } \\
\text { index } \\
\text { - ANOVA test } \\
\text { - } 172 \\
\text { Innovative } \\
\text { (TOP } 100 \\
\text { Project in } \\
\text { Germany) }\end{array}$ & $\begin{array}{l}\text { - Provided conceptual and } \\
\text { empirical framework that } \\
\text { advance the literature on } \\
\text { measurement of } \\
\text { organizational innovation } \\
\text { - Proposes a '3P' construct } \\
\text { of innovation } \\
\text { measurement that } \\
\text { simultaneously considers } \\
\text { the Posture, Propensity } \\
\text { and Performance }\end{array}$ & $\begin{array}{l}\text { Limited } \\
\text { indicators }\end{array}$ & $\begin{array}{l}\text { Contingent variations } \\
\text { of Composite } \\
\text { Innovation Index (CII) }\end{array}$ \\
\hline Auken et al (2008) & $\begin{array}{l}\text { Survey in } \\
\text { Spanish } \\
\text { manufacturing } \\
\text { SMEs }\end{array}$ & $\begin{array}{l}\text { - Innovation positively } \\
\text { impacts SMEs } \\
\text { performance in low and } \\
\text { high technology industries } \\
\text { - Innovation was more } \\
\text { important to achieving a } \\
\text { competitive to high } \\
\text { technology firms than low } \\
\text { technology firms } \\
\text { - These result support } \\
\text { innovation as being } \\
\text { important to a firm's } \\
\text { sustainable competitive } \\
\text { advantage }\end{array}$ & $\begin{array}{l}\text { The data was } \\
\text { also collected } \\
\text { at a single } \\
\text { point in time }\end{array}$ & $\begin{array}{l}\text { A longitudinal study } \\
\text { could provide } \\
\text { evidence on he } \\
\text { changes in evaluation } \\
\text { over time }\end{array}$ \\
\hline Rosenbusch et al & $\begin{array}{l}\text { Meta-analysis } \\
\text { Synthesizes }\end{array}$ & $\begin{array}{l}\text { - Innovation-performance } \\
\text { relationship is context } \\
\text { dependent } \\
\text { - Factor such as the age of } \\
\text { the firm, the type of } \\
\text { innovation, and he cultural } \\
\text { context affect he impact of } \\
\text { innovation on firm } \\
\text { performance large extent }\end{array}$ & $\begin{array}{l}\text { A number of } \\
\text { importance } \\
\text { contextual } \\
\text { factor }\end{array}$ & $\begin{array}{l}\text { Can be directed at } \\
\text { uncovering other } \\
\text { moderators and } \\
\text { illustrating specific } \\
\text { mechanism hw } \\
\text { innovation affect firm } \\
\text { success }\end{array}$ \\
\hline Authors (Year) & Method & Key Finding & Limitation & $\begin{array}{c}\text { Future Research } \\
\text { Direction }\end{array}$ \\
\hline Gunday e al (2011) & $\begin{array}{l}\text { A questionnaire } \\
\text { was developed } \\
\text { and a survey } \\
\text { was conducted } \\
\text { in the years } \\
2006 / 2007 \\
\text { within of } 7 \\
\text { months }\end{array}$ & $\begin{array}{l}\text { - The positive effects of } \\
\text { innovations on firm } \\
\text { performance in } \\
\text { manufacturing industry } \\
\text { - Organizational } \\
\text { innovations play a } \\
\text { fundamental role for } \\
\text { innovative capabilities as } \\
\text { it has greatest regression } \\
\text { coefficient with innovative } \\
\text { performance }\end{array}$ & $\begin{array}{l}\text { Limited as a } \\
\text { period time }\end{array}$ & $\begin{array}{l}\text { Requires longitudinal } \\
\text { data }\end{array}$ \\
\hline Maleyeff (2011) & $\begin{array}{l}\text { Analyzed based } \\
\text { on Field } \\
\text { research results } \\
\text { from } 84 \text { service } \\
\text { innovation } \\
\text { project }\end{array}$ & $\begin{array}{l}\text { - although personal } \\
\text { characteristics, process } \\
\text { type, or customer type do } \\
\text { not affect the level of } \\
\text { innovation, organizations } \\
\text { with a strong lean six } \\
\text { sigma orientation had a }\end{array}$ & $\begin{array}{l}\text { Not very strong } \\
\text { incentives }\end{array}$ & $\begin{array}{l}\text { Need to be } \\
\text { implemented in } \\
\text { organizations to } \\
\text { ensure that employees } \\
\text { develop more radical } \\
\text { innovations }\end{array}$ \\
\hline
\end{tabular}




\begin{tabular}{|l|l|l|l|l|}
\hline & & $\begin{array}{l}\text { lower incidence of radical } \\
\text { innovation } \\
\text { recommendations }\end{array}$ & & \\
\hline $\begin{array}{l}\text { Damanpour et al } \\
(2009)\end{array}$ & $\begin{array}{l}\text { Longitudinal } \\
\text { study }\end{array}$ & $\begin{array}{l}\text { Focus on adopting a } \\
\text { A panel data of } \\
\text { specific type of innovation } \\
\text { every year is detrimental, } \\
\text { consistency in adopting } \\
\text { the same composition of } \\
\text { service } \\
\text { innovation type could } \\
\text { organizations in } \\
\text { UK over four } \\
\text { possibly be beneficial to } \\
\text { organization performance }\end{array}$ & $\begin{array}{l}\text { Test concern in } \\
\text { service } \\
\text { organization }\end{array}$ & $\begin{array}{l}\text { Examine in } \\
\text { manufacturing } \\
\text { organization }\end{array}$ \\
& & \\
& & \\
\end{tabular}

